\title{
THE IMPACT OF ANTI-BLACK RACISM ON BLACK MALES
}

by

Rick Acheampong, BSW, Ryerson University, 2016

\author{
An MRP \\ presented to Ryerson University \\ in partial fulfillment of the \\ requirements for the degree of \\ Master of Social Work
}

Toronto, Ontario, Canada, 2019

(C) Rick Acheampong, 2019 


\section{AUTHOR'S DECLARATION}

I hereby declare that I am the sole author of this MRP. This is a true copy of the MRP, including any required final revisions.

I authorize Ryerson University to lend this MRP to other institutions or individuals for the purpose of scholarly research

I further authorize Ryerson University to reproduce this MRP by photocopying or by other means, in total or in part, at the request of other institutions or individuals for the purpose of scholarly research.

I understand that my MRP may be made electronically available to the public. 


\author{
ABSTRACT \\ The Impact of Anti-Black Racism on Black Males \\ Master of Social Work, 2019 \\ Rick Acheampong \\ Social Work \\ Ryerson University
}

This paper examines the lived experiences of racialization, oppression, criminalization, and discrimination upon Black males living in Canada. The theoretical framework for my research was comprised of anti-Black racism and Critical Race Theory. These frameworks guided my research into the lived experiences of anti-Black racism against Black males. The research study used a narrative approach where Black male participants shared stories of antiBlack racism. The research entailed asking participants open-ended questions about their lived experiences of anti-Black racism and the impact it has had on their lives. The findings from the research highlighted how marginalized and racialized groups in Canada practice anti-Black racism towards Black people within public spaces. It also showed the anti-Black racism that police officers engage in against Black males within institutions that have a history of being antiBlack. The findings showed the lack of self-awareness and white supremacist beliefs that racialized groups embody when perpetuating anti-Black racism. Also, it highlighted the continuous practice by police officers who racially profile and incarcerate Black males due to their skin color. The conclusion from the study highlighted that Black males continue to experience anti-Black racism within agencies that make up the criminal justice system and the anti-Black racism that marginalized groups engage in when interacting with Black bodies. 


\section{ACKNOWLEDGEMENTS}

The Faculty of Community Services and the School of Social Work generously supported this work at Ryerson University. I am especially grateful to all members of the faculty staff that have contributed to my learning journey as a Ryerson graduate.

I would also like to thank family and friends who supported and mentored me throughout the course of my study. My mother Gladys, sisters Beverly and Natalie, friends Sean, Ronald, Che and Kevin; and to many more family and friends of which there are too many to mention.

I must give a special thanks to Gordon Pon and Rene Ferguson for their knowledge and critical reading of content by Akua Benjamin, Robyn Maynard and Delores V. Mullings, Anthony Morgan, and Heather Kere Quelleng. 


\section{TABLE OF CONTENTS}

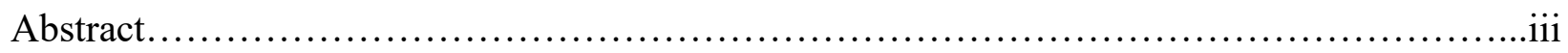

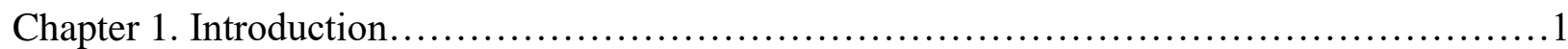

Chapter 2. Literature Review.....................................................4

Chapter 3. Theoretical Framework................................................ 14

Chapter 4. Methodology........................................................20

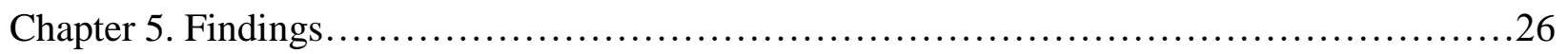

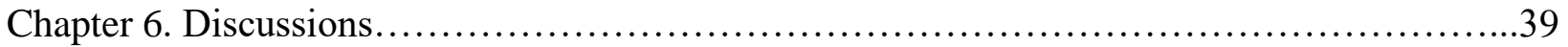

Chapter 7. Conclusion........................................................ 45

Appendices....................................................................... 47

References..................................................................55 


\section{Chapter 1: Introduction}

The rationale for my selecting anti-Black racism and its impact on Black males as the topic of my Major Research Paper (MRP) is mainly due to its continuous impact on all Black people. It affects all Black people in many different ways, and my hope is to shed light on the encounters of anti-black racism from a Canadian experience. A second rationale for selecting anti-Black racism is because for centuries, Black peoples' experiences and stories of oppression have been silenced and unacknowledged, which has led to a substantial impact on their lives, mentally, socially, psychologically, economically, and spiritually. A final rationale is due to post-traumatic slave syndrome. Mullen-Gonzalez (2012) argues that post-traumatic slave syndrome is a condition that exists when a population has experienced a multitude of generational trauma, resulting from centuries of psychological and emotional enslavement and continue to experience oppression and institutionalized racism.

Due to the lack of research among Canadian scholars on post-traumatic slave syndrome, the impacts it has had on African Canadian males and its interconnection with anti-Black racism, I have chosen it as my topic of study. Thus, this paper seeks to bring light to these interconnections by providing a deeper understanding of the experiences of anti-Black racism as experienced by Black-Canadian males.

The reason why the topic of anti-Black racism is essential to me is due to a number of reasons. First, the impact anti-Black racism has had on my personal identity occurred when I was internalizing oppression at a young age, which led to believing that Black males can only aspire to be athletes, musicians, or criminals. These narratives were internalized as truth, which resulted 
in me engaging in such activities in order to uphold these narratives. It was not until years later when I learned that what I was experiencing was the internalization of the belief that Black people were inherently inferior to white people; moreover, I began seeing how family members and friends were also experiencing and suffering from internalized oppression. Mullaly (2010) referred to internalized oppression as behaviors that are self-harming and contribute to one's own oppression and is not limited to holding the belief that one group is inferior to another.

The experiences of internalized oppression are influenced by the stereotypes, propaganda, and false narratives of Black people. Internalizing these dominant ideas as truth have negative impact upon Black males and females. Lastly, I believe it's important to not only show Black male youth that these dominant beliefs and stereotypes are untrue, but that they also have the power and right to change these false narratives that have been depicted by society for centuries.

The importance of addressing my reflexivity and the importance of representations is discussed by Creswell. Creswell (2007) articulates that how we write is a reflection of our own interpretation based on our cultural, social, gender, and personal politics, which we bring to our research. My experiences with anti-Black racism have impacted me culturally, socially and personally. Due to anti-Black racism impacting my life on many different levels, I feel that it's important to gather the many unheard stories of anti-Black racism and the many different ways it has affected black males living in Canada. Creswell (2007) contends that no writing has privileged status and that writing is co-constructions which involve both the researcher and participants. This collaborative approach brings forth the importance that no one traumatic experience with anti-black racism is more significant than the other. 
As a Black social worker, my personal epistemology is working through an Afrocentric lens, which involves working with Black people as partners and incorporating Black service users in every discussion and plan. Mathabane and Sekudu (2018) speak to how African social work is based on African beliefs, ideas, and values, which center on involving Black Africans. I believe as a Black social worker that it is essential to work through such lenses, due to the many oppressions that Black people encounter on a systemic level and personal level, and the related impact that anti-Black racism has on Black people's mental health.

My overall purpose for addressing the impact of anti-black racism on Black males is bringing awareness to this issue. This includes, but is not limited to, discussing the engagements through the criminal justice system and its impact on the mind psychologically, which can be linked to post-traumatic slave syndrome. My objective is to influence future Black social workers to conduct research papers on anti-Black racism and to increase the amount of Canadian literature on the history of slavery and its influence on anti-Black racism. Maynard (2017) referred to slavery as being under-taught and under-researched in Canadian schools. Relatedly, there is an absence of Black studies departments in Canadian universities. 


\section{Chapter 2: Literature Review}

The purpose of this literature review is to examine studies by researchers who address the many different ways that anti-Black racism impacts Black males. The literature review is first organized around three main themes which are anti-Black racism, slavery and criminal justice. The literature will then discuss the paradigms and theoretical frameworks that were used by the researchers. The strengths and weaknesses of these themes will be analyzed before discussing the disciplines that have contributed to anti-Black racism and the ways in which anti-Black racism continues to exist. Lastly, the methodologies/methods used by the researchers and the individuals involved and excluded from their literature will be reviewed.

The first theme that will be addressed is anti-Black racism. Kumsa, M'Carthy, Oba, and Gaasim (2014) discussed three types of anti-Black racism. The first is anti-Black racism, which is racism directed towards Black people. Kumsa, M'Carthy, Oba and Gaasim (2014) stated how it is Black youth who are being shot, being unemployed in excessive numbers, being inappropriately streamed in schools, disproportionately dropping out, and where community housing with large concentrations of Black residents consume a sense of vulnerability and disadvantage. The second type is anti-Black-African racism. Kumsa, M'Carthy, Oba, and Gaasim (2014) addressed how anti-Black-African racism is inflicted upon Blacks from Africa as opposed to whites and browns from Africa. Also, Fanon (1952) speaks of how Black Africa evokes imaginaries of backwardness and uncivilized savages, zombies, and cannibals. The third is anti-Black-racism, which is racism perpetrated by Blacks toward Blacks. Although anti-Blackracism has two aspects that are similar, they are also not mutually exclusive, and though they are connected, you cannot explore one without the other. 
The second theme that will be discussed is slavery, and the intergenerational trauma it has caused among Black male youths in inner cities. Mullen-Gonzalez (2012) speaks to inner city youth, particularly African American youth who experience high rates of trauma. Also, their trauma symptoms are often treated as externalizing behaviors or punished by sentencing within the prison and juvenile justice systems. Additionally, unrelenting experiences of prejudices and barriers to success produce disillusionment and frustration among many African American males. Gump (2010) addresses that there was little in slavery that was not traumatic, from the loss of culture, homes, kin, attendant sense of self, destruction of families by the physical, mental, and emotional abuse, and witnessing the castration of fellow slaves. Maynard (2017) refers to slavery as setting the stage for centuries of the dehumanization of Black life across Canada and the social forgetfulness about slavery in Canada. This has led to the impossibility for many people in Canada to understand anti-Black policing, over its period of time in Canada.

Hardy (2013) discusses using validation in addressing trauma amongst racialized youth. It counteracts devaluation, and the assaulted sense of self. The assaulted sense of self as defined by Hardy (2013) is a hidden trauma that is closely tied to internalized devaluation and racial oppression. The assaulted sense of self is the apex of recurring experiences with internalized devaluation. It becomes challenging to develop a healthy sense of self when one is constantly bombarded with messages that they are unattractive, not smart, etc. Hardy (2013) also discussed the significance of a global knowledge of race; validation provides confirmation of a youth's worldview and worth. Also, Wade (2017) asserts that fields such as social work and social services have lacked an understanding and use of tools that account for the influence of intergenerational trauma from events such as slavery. 
The final and third theme that will be summarized is the criminal justice system. Reasons et al. (2016) discussed that racial/ethnic data are not generally collected in Canada and the collection of such data would ruin the multi-cultural image of Canada as a place of acceptance and tolerance. Additionally, Reasons et al. (2016) alluded to a long debate among academics on whether data should be collected and if such practice will be more harmful. Reason et al. (2016) argue that although race statistics are not collected, the Canadian media presents a negative image of Black males to the Canadian public. Wilson and Sparks (1999) alluded that theories of Black representation in mass media tend to focus on narratives that are stereotypical, and mass media are an important site for the production, reproduction, and transformation of racial ideologies.

There is also data that is collected within corrections, which shows that Black males are overrepresented in segregation and in closed confinements within the prison system. Brunson and Miller (2006) discuss how research indicated that punishment by correction officers on Blacks was consistent and severe and Blacks were also experiencing racist language on a routine basis. Also, Brunson and Miller (2006) addressed how very few research studies have examined police/suspect encounters from the point of view of those suspected and stopped by the police. Brunson and Miller (2016) argue that police misconduct usually occurs against communities that have a large African population. They referred to their studies showing that Black male participants have negative experiences with police relations. Maynard (2017) speaks to the importance of understanding the relationship between Black bodies, inferiority, and pathology, and also understanding the subjugation of Black life through policing and other state institutions. 
The paradigms and theoretical framework that were evident throughout the articles were the Black-White epistemological paradigms, critical intersectional paradigms, and critical race theory. The first epistemological paradigm that was regularly seen in the literature was the Black-White racial epistemology. Hunter (2002) addressed this epistemology as African Americans being the only race who have had a real experience of racism. In many of the articles, the racism experienced by African Canadians during encounters with Toronto police officers were evident throughout. Very few Canadian journal articles discussed the murders of Black youths by Canadian police officers.

The epistemology of critical intersectionality was also expressed throughout the articles. Stories of African Canadian women experiencing racism and sexism was also expressed in the articles. Mullings, Morgan, and Quelleng (2016) share the story of Audrey Smith a tourist, public sector worker and mother of five from Jamaica, who spoke of being strip searched and feeling naked as the day she was born. Hunter (2002) discusses how this epistemology understands oppression whereby racism and sexism are not separate but inherently connected to any racial identity, which is gendered. Hunter (2002) also addresses the need for multiple viewpoints within critical intersectionality but focusing attention on the analysis of the group itself.

Critical race theory was also the core framework of knowledge that was vivid during the readings of the articles. Mullings, Morgan, and Quelleng (2016) referred to the core tenants of critical race theory, as centralizing the voices, experiences, and perspectives of racialized people. In addition, using this practice of centralizing racialized voices can frame and direct the assessment of dominant norms within systems, institutions, and practices. 
The strengths of the paradigms and theoretical frameworks were the connections that were made between the paradigms and theories. For example, Mullings, Morgan, and Quelleng (2016) speaks to how critical race theory can be categorized as a race-conscious approach to examining the law and the legal system and its impact on the marginalization and subordination of racialized people. They also address how critical race theory recognizes that the conventional way in which systems and structures are governed is not race-neutral but are structured indirectly and directly to sustain white supremacy.

The strength of critical race theory is the discussion and analyzing of the systems in place that cause harm towards marginalized and racialized groups during police engagements. An example would be the many injustices of young Black males who are murdered by Toronto police officers. A crime that not only has its histories in the United States of America but also in Canada. Mullings, Morgan, and Quelleng (2016) discuss the killing of Michael Wade in 1988, who was an unarmed Black male who was murdered by Toronto police officers, while the charges against the officers were dropped.

A second strength of the paradigms and theoretical frameworks is the space for the scholars to be self-reflexive with their experiences as it pertains to anti-Black racism. An experience that scholars Kumsa, M'Carthy, Oba, and Gaasim (2014) referred to as reflexive wrestling. Kumsa, M'Carthy, Oba, and Gaasim (2014) speak to how stunned they were by the experiences of youth violence denoted by the participants in their study; the violence resonated deeply within their own bodies; this resonation was linked to critically examining the violence of anti-Black racism in their own bodies. Hunter (2002) addresses reflexivity as a continual selfawareness. This allows the researcher to become more aware of producing knowledge, beliefs, 
backgrounds, and feelings during research. The scholars also acknowledged how anti-oppressive practice is unique to each person and that their stories highlight the multiplicity of ways people engage anti-oppression.

A major limitation revealed in the literature I reviewed was that the epistemological paradigms and theoretical frameworks failed to address the experiences of anti-Black racism by Black LGBTQ individuals. The literature also did not delve deeply into the trauma that Black males and females experience. It also excludes Black LGBTQ members which elides the knowledge, stories, and experiences of these individuals, who also experience anti-Black racism. These theories also fail to acknowledge the impact of intersectionality when it pertains to the experiences of anti-Black racism by Black LGBTQ members in public and private spaces. Bailey (2014) discusses the experiences of Black LGBTQ members from the ballroom community that suffer spatial marginalization, being structurally prohibited, denied access and oppressed within public and private spaces due to race, gender, and sexual identities.

Articles that discussed the connection between race and the criminal justice system also excluded the stories and experiences of Black LGBTQ members and their history with the criminal justice system. Graham (2014) states that Black transgender youth are punished and criminalized by some police, who view their gender nonconformity as a marker of social deviance. An additional limitation in the paradigms and theoretical frameworks is the lack of historical acknowledgement of colonialism, racism, loss of land, murder, abuse, and oppression, of Black African Americans who identify as Indigenous.

Sharma and Wright (2008) addressed how anti-racist theory and practices have historically excluded the concerns of Aboriginal people who identify as native Africans. In 
addition, Mullen-Gonzalez (2012) also discusses how in clinical studies and journals, the DSM does not reflect the Indigenous experience, and perspectives by Indigenous researchers closely mirror the kidnapping, assimilating and historical grieving of Africans in the United States of America today.

There are a number of disciplines that contributed to the study of anti-Black racism. The specific disciplines include psychology, criminology, social work, Indigenous studies, critical race studies, Black studies and Black Queer Studies. In the psychology studies, they discuss psychodynamic theory, a theory that explores the unconscious and the defensive development of a traumatized individual. Mullen-Gonzalez (2012) refers to psychodynamic theory as the unconscious mind which can be brought to the physical world in many ways and collaborated through artwork. This could serve as a creative tool that can be used by therapists when working with racialized groups. This practice by therapists positions oneself to think symbolically about their experiences.

In criminology, the studies examine the aggressive and the disrespectful encounters police engage in with Black males, who police deem to be resistive or non-compliant. Also, they address the adverse actions by police within communities that consist of a large community of racialized people. The articles examined that when police behavior is taken to account, marginalized groups are more likely to comply. In the clinical studies, they emphasize that Black males have been under and over-represented in diagnosis in clinical settings. Atkins, Macdonald, and Mitterling (2015) alluded that African American men have been overrepresented among racial groups that have been misdiagnosed and underrepresented among racial groups. They also 
acknowledge that they do not argue for or against specific diagnoses, but for clinical practices to incorporate social and historical analysis into psychological assessments.

Lastly, Indigenous studies have contributed to the knowledge by contributing education on Indigenous perspectives on trauma. Mullen-Gonzalez (2012) addressed that when Indigenous healers speak of symptom-oriented problems in marginalized and racialized communities, they speak to the ideas of spiritual injury, social sickness, soul wounding and ancestral hurt.

In the Kumsa et al. (2014) article, the methodology and methods of data collection that were used to gather knowledge was conducted in connection with a funded project that consisted of Black male youth groups. The methodology used consisted of a reflexive approach, where the researchers interviewed the participants on their personal experiences of anti-Black racism while acknowledging their own experiences of anti-Black racism and being self-reflective of their feelings to their cultural and structural roots. An innovative method was used to collect data, which consisted of a combination of evocative activities around image, performance and symbolic objects which were carried out in small conversation groups. The findings illustrated that violence and healing were inseparable and intertwined. In addition, counter storytelling was also used as a method to gather knowledge. Mullings, Morgan, and Quelleng (2016) referred to counter storytelling as the use of parables, autobiography, and alternative narratives to attack dominant myths, beliefs, and narratives that marginalize racialized communities.

Strengths related to the methods used to collect data were the opportunities for participants to share their stories and lived experiences. Kumsa, M'Carthy, Oba, and Gaasim (2014) discussed how storytelling is a path to profound healing in many oppressed communities and that storytelling is poignant for Black Africans, from rich oral cultures and that it connects 
them to places of dignity and communities of belonging. An additional strength is the voices of Black women being heard and their experiences to anti-Black racism. Intersectionality was also discussed, an important topic to address, since the voices of racialized women are usually not heard equally and experience racism in combination with sexism, classism, and other intersecting identities that structure inequality.

The limitations of the methodology and methods used in the literature I reviewed were the model programs; they provided no empirical evidence regarding efficacy. It also excluded Black LGBTQ members that could have benefited from the program. Also, the length of the programs can be argued that they were too long for a group that was known to not comply with treatment and did not trust the mental health system since the programs were funded by health institutions. And lastly, limitations to the model programs were limited in focusing on their specific population which was African American adolescent males living in inner cities.

The individuals involved in the studies had the lived experiences of anti-Black racism by Black women and Indigenous persons who identify as African American. Mullings, Morgan, and Quelleng (2016) discussed how the stereotypes of Black women being baby hatchers or coined welfare queens is prominent in Canada and motivates in-depth scrutiny of Black women. Although the stories of Black women were involved in a few of the articles, their stories of oppression within clinical institutions were never addressed. The disproportionate number of misdiagnoses of Black women was never shown in the clinical journals. Meerai, Abdillahi, and Poole, (2016) mention that when it comes to addressing the discrimination and overrepresentation of African/Black people in the mental health system, it should be viewed through the lens of anti-Black sanism. 
Also, Meerai, Abdillahi, and Poole, (2016) describe how Black women have been attacked with negative images such as stereotypical mammies, matriarchs, welfare recipients, which assists in sustaining the oppression of Black women. A second group that was excluded and addressed earlier in the paper was the anti-Black racism that Black LGBTQ members experience in society and the lack of information about their experiences with the criminal justice system.

The epistemological issues in the literature I reviewed revealed a general lack of reflexivity and situating of themselves as white scholars in the clinical research articles on disorders of diagnosed young Black males. Langhout (2006) addressed the importance of selfsituating and being reflexive since it is central in the work of community psychology and that is anti-Black racism towards Black LGBTQ members and being self-reflexive as to why their stories and experiences are not being addressed in academic journals. As a researcher, it is important that I be self-reflexive around my social location and privilege as a heterosexual male, who has been privileged to discuss issues of anti-Black racism and acknowledge the complexity of intersectionality within Black LGBTQ individuals. 


\section{Chapter 3: Theoretical Framework}

The main theories that will be used to guide the Major Research Paper will be critical race theory and anti-Black racism. The paper will use these theories, to address the racism that black males experience politically, economically, and systemically. This paper will also analyze the impact racism has had on Black males emotionally, mentally and spiritually. Delgado and Stefancic (2017) spoke to the three tenants within critical race theory; the first tenant is that racism is ordinary, which makes it difficult to confront because it is not acknowledged. The second tenant is interest convergence, where racism advances the interest of the dominant group, where whites are advanced materially and the working class psychically. And the third tenant being social construction where race and races are products of social thought and relations. In other words, races are categories that society has invented to manipulate or retire when convenient.

This theory also provides storytelling, which is essential within critical race theory and anti-Black racism. Delgado and Stefancic (2017) discussed that in critical race theory, stories give marginalized and oppressed groups a voice, and reveals that all marginalized groups share similar experiences. Delgado and Stefancic (2017) suggests that within critical race theory, it's important to bring forth a language that bridges the gaps in imagination and conception for people who are considered different. Critical race theory and anti-Black racism allow marginalized groups to provide their own narrative stories and reduces alienation and allows the dominant group to meet excluded groups half way. The reasoning for choosing critical race theory is the interconnected relationship that race, power, and racism have with one another. 
Also, the tenets of critical race theory are critical in addressing the anti-Black racism experienced by Black males.

The second theory that will guide my research study is anti-Black racism. Mullings, Morgan, and Quelleng (2016) described anti-Black racism as prejudice, stereotyping and discrimination that is directed only towards people of African descent, which is also rooted in the historical enslavement of African people and the unique history that Black people have within the western world. Kumsa, M'Carthy, Oba, and Gaasim (2014) also identified anti-Black racism as a type of racism that is directed towards black people who continue to experience antioppression as employees, professionals, and as non-professionals.

One of the most useful frameworks within critical race theory is its approach to antiBlack racism. Mullings, Morgan, and Quelleng (2016) discussed the race-conscious approach to examining the law and the legal system as well as its implications for marginalized and racialized groups. Crenshaw (1988) talks about the role that racist ideology plays within the legal system and law. She goes on to mention how racist ideology historically created a hierarchical order/category that deemed Blacks as subordinate and separate, which has also been ingrained into law and customs.

Brunson and Miller (2006) describe Black males as symbolic assailants within the criminal justice system, whose characteristics and behaviors are deemed as threatening during police interactions. This notion has aided minority theorists in being successful in explaining police brutality and deadly force. Kumsa, M'Carthy, Oba, and Gaasim (2014) addressed how Black youths are at the bottom of the hierarchy of oppression and constantly experiencing the racial violence, front and center. There have been many instances of Black youth experiencing 
not only racial discrimination by police officers but also being killed by police officers. Within critical race theory, it provides an outlook on the racist ideology within the law and legal system. Crenshaw (1988) argues that not only should we look into how the legal system oppresses marginalized groups but the ways in which the systems in place seem neutral and acceptable. And that the most effective kind of domination, is domination that is practised and believed in by white society.

One of the core tenets of critical race theory is the availability of the voices of racialized groups to be heard. Delgado and Stefancic (2017) allude to how counter-storytelling challenges, displaces, or mocks societies' dominant narratives and beliefs of racialized communities. According to Mullings, Morgan, and Quelleng (2016) counter-storytelling is used as parables, autobiography, counter-stories, and alternative narratives to attack dominant social preconceptions, myths, beliefs and narratives that marginalize. Within the articles that incorporate critical race theory, they bring forth experiences of racism, oppression, and discrimination by systems that practice anti-Black racism.

The counter-stories critique and analyze the experiences of violence and force by law enforcement which can also date back historically. Maynard (2017) discussed how during the abolition of slavery, advertisements were used to capture slave freedom seekers who had escaped bondage. Throughout history, the association of blackness and criminality has always been closely aligned. Delgado and Stefancic (2017) addressed how stories have a valid destructive function, but over time, society has constructed a world mediated by images, pictures, and social media. Also, it is vital to challenge preconceptions of marginalized groups. 
A final concept that will be addressed within critical race theory is post-traumatic slave syndrome. Leary (2005) defines post-traumatic slave syndrome as a condition, where a population has experienced multigenerational trauma. This trauma has resulted in centuries of psychological, emotional enslavement and these populations continue to experience oppression and institutional racism. There are three categories of behaviors that are associated with posttraumatic slave syndrome.

Vacant-esteem is the state when someone believes that they have little or no worth. It is usually compounded by society's belief, stereotypes and preconceived notion that Blacks are inferior. Secondly, anger, as Leary (2005) describes, as a normal emotional response to a blocked goal, and when that goal is blocked over a period of time, we become fearful which then lashes out into anger. The final category being racist socialization. Research suggests that it is common within people who have been captive, to take on their captor's views and beliefs. One of the most insidious symptoms of post-traumatic slave syndrome is the adoption of the slave masters' value system. In this value system there is the belief that whites, and all things associated with whiteness is superior and all things associated with Blackness is inferior.

The relevancy of anti-Black racism is it presently and continuously affects Black males today. Many critical race theorists explore the disproportionate criminalization of Black bodies, which has had a long historical past, where Black bodies were not and continuously remain to be non-human beings. The history of Blacks being viewed as inferior is addressed by Deliovsky and Kitossa, (2005) referring to a Spanish colonist called Bartolome de Las Casas, who said that Indigenous people were children of God and should be spared genocide while brutality should be enforced on Africans since they are cursed. Ray, Randolph, Underhill, and Luke (2017) 
discussed that slavery produced Blacks as being considered as non-humans, which brought forth the ownership of their bodies.

These practices continue today in the form of racial profiling and carding, which are all practiced by the criminal justice system. Racial profiling and carding not only targets Black males but also sees them as property that needs to be contained. Maynard (2017) mentions that despite the end of Black bodies being in bondage during slavery, Black bodies continue to be devalued, and their movements are subject to surveillance and containment. These practices of policing Black bodies still continue today. Mullings, Morgan, and Quelleng (2016) addressed how policing techniques and activities of racial profiling are used to stereotype, stigmatize, harass, and discriminate against African Canadians.

Additionally, by combining critical race theory and anti-Black racism, this will allow Black males to tell their stories of discrimination, oppression, hate, abuse, racial profiling by institutions that continuously oppress and target Black males. Research articles that address antiBlack racism and its impact upon Black people describe in depth the importance for Black people to discuss their experiences, stories, and truth when it comes to anti-Black racism. Researchers, realizing the impact of hearing stories of anti-Black racism, in turn encourage themselves and others become more reflective of their own experiences of anti-Black racism. Kumsa M'Carthy, Oba, and Gaasim (2014) touched on how astounded the researchers were by the stories of anti-Black racism and how the tensions of anti-Black racism were also the same tensions that the researchers were experiencing when it came to their own personal experiences of anti-Black racism. Delgado and Stefancic (2017) speak to how stories reveal that other people 
have similar experiences and stories can name a type of discrimination, whether microaggression or structural racism, and once named, it can be combated. 


\section{Chapter 4: Methodology Introduction}

The qualitative approach to my research was a narrative approach. The reason for the narrative approach is due to its premise of allowing participants to speak and write to make meanings of their life stories. Padgett (2017) discusses how life histories, biographies, folk tales, and psychotherapy, are grounds for narrative knowing. A narrative approach allows the Black male participants who I interviewed to share their life histories and biographical experiences of anti-Black racism. Clandinin and Connelly (2000) assert that experience is both personal and social and are always present, and that people cannot be understood as individuals, but must be understood in relation to their social realities. However, Black males are usually never understood in relation to their social context. Rather they are often stereotyped, assumed or deemed to be criminals, thugs, dangerous, and bad.

A second important aspect of the narrative approach is that of continuity. Clandinin and Connelly (2000) speak to the notion that experiences grow out of experiences and they also lead to other life journeys. And that past experiments lead to an experimental future that is forthcoming. The narrative approach grants the Black male participants, to not only share past experiences of anti-Black racism, but also stories of how the experiences have a history that is always changing and is always going somewhere. Clandinin and Connelly (2000) spoke of an example of a child's learning in a school where their history is always changing and going somewhere. A narrative approach opens doors for participants to give an account of experiences that are linked sequentially. Creswell (2007) alludes to narrative as being spoken, giving an account of events which are chronologically connected. The participants will also be given the 
opportunity to discuss their stories of anti-Black racism within a historical context, which will date back to their earlier memories of experiencing this form of oppression.

\section{Rationale for Research Design}

The research design entailed open-ended questions, which allowed the researcher to listen to the participants and refrain from being an expert of their lives. Creswell (2007) argues that we ask open-ended questions to explore and withhold from assuming the role of an expert researcher. The rationale for this design is that is entails a freedom for participants to be the expert of their lives since it is their lived experiences.

The second rationale for this design is that it allows the researcher to collect details of key events and compile the findings into a story. Creswell (2007) refers to this as narrative analysis, which holds a particular subject where stories of detailed events, configure into a story using a plot line. More importantly, my epistemology was the rationale for the research design. My open-ended research questions come from an Afrocentric perspective that privileges African people as a starting point. Mathabane and Sekudu (2018) argues that Afrocentricity refers to a way of being which includes thinking and writing from a place that benefits Africa, as a beginning stage of subjectivity and analysis. The strengths of asking open-ended questions as a design is that it highlights, and challenges perceived beliefs that anti-Black racism no longer exists in Canada. It also allows for the participants to share the many and different types of antiBlack racism that are targeted against Black people. In general, most people in Canadian society are not familiar with the different types of anti-Black racism that are perpetrated against Black people. Kumsa, M'Carthy, Oba, and Gaasim (2014) assert that anti-Black racism does not affect all Black people the same way and the practice of anti-Black racism has varying contours. 
A weakness to the design of the research studies I reviewed is they do not explore intersectionality and the impact it has on the participant's experiences to anti-Black racism. However, this is addressed in the earlier part of the paper, when I discuss the importance of including Black LGBTQ members since their lived experiences of anti-Black racism are interconnected to multiple layers of oppression such as homophobia, transphobia, sexism, and anti-Black racism.

\section{Methods}

\section{Recruitment and Sampling techniques}

The recruitment strategy involved recruiting individuals I personally knew, who have experienced anti-Black racism. Creswell (2017) addressed that in a narrative study, a researcher needs to find individuals who are accessible and extraordinary, in the accomplishments they have achieved in their own unique way and can also shed light on a specific issue that is being explored. The sampling technique for the research study was a purposive technique. The reason for choosing a purposive sampling technique is it provided the required data for the study on experiences with anti-Black racism. Padgett (2017) describes purposive sampling as an intentional process of selecting volunteers based on their ability to provide needed information. The participants shared their first-hand stories to the research questions. Creswell (2007) refers to this process as first-order narrative, where participants tell stories about themselves and their own experiences.

During the recruitment process, there was a written script, which was to be used over the phone to ask potential participants if they would be available to be a participant in the research study. However, if they were not available, I then asked if they knew of individuals who might 
be interested in being a part of the research. Before participants were asked to participate, they were told what the study is about and what the study will encompass. Padgett (2008) asserts that that at all times, a script should be ready, either written or verbal. The script provided a brief description of what the study is about and what participation will entail.

\section{Data Collection and Instruments}

The method for data collection involved open-ended questions. The interviews were oneon-one interviews. The semi-structured interview was audio recorded and transcribed.

Depending on the availability of the participants, a telephone interview was to be conducted if a participant was unavailable for a one on one interview. The reason for the method of data collection being in the form of an interview is because it brings forth stories by the participants. Creswell (2007) explains that in a narrative study, there are three ways to collect data and all forms include telling a story.

The first being the recording of spontaneous incidents of storytelling; the second is eliciting stories through interviews; and the third, asking for stories through a medium such as the internet. The one-on-one interview was scheduled in advance and transpired in a space that was confidential and planned in advance. Padgett (2017) contends that in-depth interviews are scheduled in advance, taking place in a private setting and preceded with careful preparation. The data analysis involved in my research included listening to the recorded audio and in doing so transcribing the audio by memoing and decoding the audio collected from the interview.

\section{Ethical Considerations And limitations}


Ethical considerations for the narrative study have all been assessed, addressed and approved by the research ethics board at Ryerson University. The necessary procedures in addressing all ethical considerations have the appropriate protocols in place. There were clear guidelines in the consent form, which addressed the potential for harm and the intentions of the study, and its necessity to be carried out. In the consent form, it states the minimal to low risk to participate in the research study and the right for the participant to withdraw before, during and after the interview. Padgett (2017) speaks to research studies that involve humans as subjects as having rules and guidelines, restricting the use of deception, and where the benefit outweighs the risk.

An informed consent form was also included as an ethical consideration. Padgett (2017) mentions since qualitative research involves face-to-face active engagement, informed consent is ongoing and a negotiated process. In the informed consent form, participants were given a brief description of the study and identification of my identity was also provided, including an address and number for future contacts. The consent form also advised participants that their participation is voluntary, and respondents have the right to withdraw at any time. A consent was provided allowing me to audio record the interview. The consent form also indicated that participants had the right to request that their interview data be withdrawn from the study. None of my participants made such a request.

Confidentiality and privacy are also jointly put in place to ensure the identities of participants are not linked to the information that they provide. Pseudonyms are used in the research to protect their identity. 
A limitation of the narrative approach is the emotional attachment to the research topic. There was the risk that the topic may fester emotions that could cause the participants to be upset, cry, or be angry during the interview. Padgett (2017) asserts that studying a close personal experience runs the risk of participants being emotionally enmeshed in their stories while they discuss their experiences. Strategies were put in place to address emotions which included participants having the right to not answer any particular question or questions, and also having the right to not continue with the study. Also, a list of resources were provided to participants, in the event that they needed additional supports. The list included organizations that provide counselling and therapy should the participants require such services to assist them in coping with any thoughts or emotions that could come up during the interview. 


\section{Chapter 5: Findings}

The first half of the findings section will address Jim and his experiences with anti-Black racism at a Chinese restaurant in Scarborough. The second portion of the findings section will address Tom and his experiences with anti-Black racism within his placement.

The analysis section will discuss the themes that stood out in each participant's interview and they will be critically analyzed through the theoretical framework of anti-Black racism.

\section{Experience with Violence}

In the beginning of the interview with Jim a theme that stood out was violence, which Jim addressed as being a part of his life while growing up in Scarborough. Jim shared that his life growing up in Scarborough was not a positive experience while seeing a lot of violence growing up. Jim shared following.

Not good man. Ahh a lot of bad experiences. Yeah, not good at all. Um a lot of gang violence. A lot of violence. A lot of negativity. Yeah wasn't good man wasn't good. Looking back at it. Yeah man I lost a lot of friends to you know, some died. Some did the killings. A lot of stuff man.

Jim discussed that during his earlier years in Scarborough, he observed someone being attacked on the same apartment floor:

In my building um somebody um. I'm guessing the guy he owed somebody money or something. So what ended up happening are these guys stopped the guy in the elevator. And they're like, yo we need our money. So he's like, I don't have it. And the man had his two daughters with him. So he told his two daughters to go back inside the house. And soon as the two daughters went inside the apartment ahh he got jumped.

Research has shown young people at a young age have been victims of seeing violence in neighborhoods that are predominately racialized and lacking in youth initiative services and programs. Brady, Smith, Henry and Tolen (2008) addressed that most youth have either heard 
about violent events or witnessed violence in their community, and many have been directly

victimized.

\section{"No Blacks" Sign}

A second theme that stood out during Jim's experiences of anti-Black racism was when

he shared seeing a sign displayed in front of a Chinese restaurant saying, "No Blacks allowed".

Jim expressed the following.

I like Chinese food. So I'm like you know what let me go in here and get something to eat. So the thing is like before I went in I seen the sign. So the sign said um no Black people allowed. So after I seen it I went in and then I stopped and I'm like you know what, let me just leave. I actually was going to go inside and ask [laughter] like kinda kinda of even even though I seen the sign I actually was gonna ask um like why is the sign up there? Can I get something to eat but because I already have dealt with a situation like that before. I'm like you know what man, let me just just leave man. That that's not the first time that's happen that's actually the second time. So I just left and went home.

Jim continued to share that his very first initial encounter with anti-Black racism,

transpired again with a Chinese restaurant:

Oh man the first time this actually happen was uh downtown. Um yeah once again you know I was hungry. And uh I like Chinese food so I seen a Chinese food restaurant place I went inside and asked the lady Um "Can I get something to eat"? And then she's like um "You didn't read the sign"? So I'm like "what sign"? So she's like "go outside and read the sign". So I went back outside and I seen a little sheet under the window and it says no Black people allowed. So then I went back inside and I'm like "why is that sign up" there? She's like we just don't accept your people. So then I just left.

\section{Paranoia and Mistrust}

Jim discussed how anti-Black racism had impacted him psychologically. A third theme

that stood out during the interview was paranoia.

Man I'm still dealing with it till today um it it definitely didn't make me feel good. Um I kinda got paranoid a bit. Like whenever I leave my house I feel like I have to deal with like racist people like I have a high chance of meeting a racist person and I have to deal with that. So I'm kind of uh paranoid about that. Um Yeah just just mentally it's messing with me mentally still. 
There has been research that has been conducted that depicts racism as causing a strain upon African Americans and is connected to psychological ramifications, which has been paranoia. Combs et. al (2006) argues that theoretical models have shared that perceived racism acts as a stressor on African Americans and can be linked to negative psychological consequences such as paranoia.

It just made me get worse like I'm already kind of paranoid already. So it just made my mental health when it comes to dealing with this worse like really worse? So..,like I really feel everybody's out to get me if you're not Black. I just feel like y'all to get me somehow I just don't trust you.

The experience of paranoia by Jim is closely linked to the thought process when Black people develop feelings of dislike towards the dominant society. Combs et. al (2006) discussed that paranoia is usually found within African Americans and that cultural paranoia is centered on the experience of being a minority in a hostile environment. There was also a connection between mistrust and paranoia, which came up during the interview. Biafora, Taylor, Warneit, Zimmerman and Vega (1993) argue that cultural mistrust is closely related to paranoia, which is believed to develop from normal and everyday events that are racist towards Black and brown bodies.

\section{Mental Health}

The fourth theme that stood out was mental health. Jim shared that overtime he had been impacted mentally by incidences of racism.

I learned that um its messing with me mentally to like I realize that. Yeah its messing with me mentally. When I'm around people that's not uh black. I act different towards them where my energy is a little different, different towards them. Cause I feel like they don't like me. So my energy is not really too friendly. 
Molina and James (2016) speak to "personally mediated" racism, which refers to discrimination based on mental health. Such discrimination involves repeated incidents of unfair treatment that trigger a host of emotional and cognitive responses. Jim's experience with anti-Black racism, speaks to the internalized oppression that many Black males internalize when consistently denied services, opportunities and being stigmatized as criminals. As a result, many young Black males in marginalized communities internalize the oppression that they experience as deserving and that it is their fault for the negative encounters that they experience in society. Jim also shared the impact anti-Black racism has had on the mental state of Black males in communities that are portrayed as gang neighborhoods:

Yeah, um a lot of people in my community there Galloway, have dealt with mental health issues and have given up. And didn't have much patience. They just gave up; they said you know what society don't love us, lets join a gang.

Molina and James (2016) addressed that internalized racism can be defined as the compliance of negative attitudes, beliefs, ideologies and stereotypes maintained by the white dominant society as being true about ones' racial group. Research on internalized racism convey to racialized people that they are different, devalued and not respected in society and this may evoke negative emotions.

\section{Media}

The last theme that surfaced from Jim's interview was the media. Jim addressed the media's portrayal of Black males as being negative and the media needing to change the depiction of Black males:

The media in general need to portray Black males in a different way. I feel like once Black males are portrayed in a different way, then other races that don't know much about Black males or Black culture uh will see Black males in a different way. And they might give them a chance instead of being negative when they see them. I feel like the media portrays Black males and Black people as bad people. So the media needs to change. Um it's how we treat Black males in the media that needs to change.

Benjamin (2003) articulates that for many centuries there have been negative depictions of Black males in the media. These images by the media help reinforce police stereotypes, beliefs, and negative 
actions towards young Black males, who are portrayed as drug dealers and pimps. The media in Canada has had a long history of associating Blackness and criminality as synonymous. Black and brown people have also detected the negative portrayal of young Black males in Canada. Maynard (2017) talks about the sentiments that were conveyed by former mayor of Toronto June Rowland, saying Black youth are responsible for the crime rates and commit more crimes than whites.

Maynard (2017) also notes that Globe and Mail columnist Margaret Wente defended the practice of racially focused policing and believing that the police are justified to assume Blacks and particularly Jamaicans are more prone to criminality. The media for a long time has always been in alignment with the dominant society's sentiment in broadcasting anti-Black messages. Wilson and Sparks (1999) argues that the media acts as agents for the status quo and plays a crucial role in reinforcing the racialization of crime using highly dramatic and evocative language when reporting crime stories involving Blacks.

\section{Participant Two's Experience with Anti-black racism}

The second portion of the findings section will depict Tom's experiences with anti-Black racism while growing up in the Oakwood and Eglinton area of Toronto and also sharing a story of being a victim of anti-Black racism within his placement.

\section{Priority Neighborhood and Transformation Period}

At the beginning of the interview Tom talked about his upbringing in the Eglinton and Oakwood area. Referring to it as a priority neighborhood where there was financial and economic challenges that individuals in the community were experiencing:

To some extent, um a lot of people in that neighborhood you know um we're not economically well off. And I'm including myself and my family, um we went through struggles financially and um, you know, had our difficulties and so I did not grow up well off. I wouldn't consider myself growing up as a middle class or upper class at all. And um you know, nonetheless, the neighborhood, the community was very lively. We supported one another, you know um it it was lots of love in the community, despite you know it being you know, for a lot of people living in the community, having financial difficulties and struggle um having to encounter a lot of, you know um hardships as I said 
financially a lot of hardships in terms of dealing with a lot of times, crime, violence you know being a disenfranchised community, that's what comes hand in hand, but poverty and so on.

Khenti (2013) addressed that the homicide rate of young Black males in Toronto should be viewed as a public health crisis; moreover, the public health perspective is supported by variables linking crime to social isolation, persistent high-unemployment and concentrated poverty. Tom went on to express that though there were economic and financial challenges within the community and his family, the neighbourhood was also a tightknit community where he was able to depend on immediate family members and rely on neighbours as extended family:

A lot of people knew each other. It was like um my immediate family was a very supportive family, my mom, my dad, um I had an older brother that you know I was raised with. Ah close auntie that lived with us for quite some time as well. And even though we were a tight knit family, it was like we had extended families from our neighbors and community members. Um so it was kind of like a village that raised me as well and um proud of that.

Tom went on to talk about finding his identity as a Black male during his transformation to being a Muslim during his high school years, and Islam being a major part in shaping the person he is today:

Islam was was the main transformative experience in my life. And um I became very um Black revolutionary in understanding who I am as a Black, diasporic, African and what that meant and slavery and who I am and my ancestors. And um my last year in high school, I became a Muslim I converted to Islam, or I should say revert to Islam, and um that Islam has really molded, you know, what I like to call the second part of my life as an adult. And um that's a huge part of my story of myself and how I grew up.

\section{The $\mathbf{N}$ word and Sports}

The N-word was a derogatory slur that Tom experienced growing up and discussed

during the interview. He shared while growing up during grade school he was called racial slurs 
by white classmates. He mentioned feeling alone and witnessing the white privilege that the white students would receive:

So there's many stories of me growing up being a young boy and being called the $\mathrm{N}$ word being called a nigger. Being called a nigger from other children, I grew up in ahh, I went to a Catholic school at the time. And in the Catholic school, there were a few um Black people in the school. I remember being in the second grade, first grade and being called by other students the $\mathrm{N}$ word. And being clearly isolated by other teachers seeing the privileges that other white students would get.

Parks and Jones (2008) allude to the word nigger being commonly used and has become particularly abusive and insulting as it pertains to African Americans. Parks and Jones (2008) also talk about the N-word being used in a race neutral manner within popular culture; while it's usage by whites is implicit in anti-Black biases and such biases predict racial hostility.

The theme of sports was also noticed and shared by Tom, talking about his experience growing up as a young Black male in grade school and being streamlined into sports by his elementary school teacher and believing at young age that he was not smart or intelligent due to his skin color:

Um being told by a teacher that on numerous occasions being told that um because of my race because of my skin color I should be doing certain things. I should focus on certain things I should focus on sports. Um athletics was always pushed in my direction, being told that maybe I I'm not good at math, or I'm not good at science. Um numerous of times. So as you can see from these, these you know these few stories, and I'm sharing that experiences of anti-Black racism starts from your very young.

Maynard (2017) argued that although systemic barriers impact all racialized youth from all backgrounds, Black youth face unique disadvantages because of the long association connecting Blackness to lack of intelligence and inferiority:

And then, of course, because I was very young at the time, I'm a school age, boy, I'm talking about grade one grade two grade three. I'm not at the capacity to really understand how to deal with this psychologically how to process this, how to fight back. Actually, what happened to me, a lot of times you start to believe this, you start to accept that this is a reality. 
Tom's experience as a young Black male of being streamed into sports displays the stereotypes and prejudices that white teachers have of Black youth. It also showcases how schools are entrenched in systemic racism, oppression, and stereotypes of Black children in their classrooms. Historically, sports has been one of the few areas where Black males are allowed to succeed.

Additionally, Ferber (2007) analyzes that the depiction of Black male athletes reinforces the historical belief that Black males are animalistic and aggressive; as a result, they need to be controlled in order to protect white women from being raped, since there has always been emphasis on the sexuality of Black males as being out of control and dangerous. Additionally, Ferber (2007) speaks to how success in the field of athletics does nothing to undermine the historical biases to reduce Black men to their bodies and attributing their talent only to their physical traits, whereas the achievements of white athletes are connected to intelligence and having moral character.

\section{White Women and Being Perceived as Criminal}

An interesting theme that stood out from Tom's interview were the words White women while sharing his experiences of anti-Black racism as a placement student and his experiences with his supervisor. Tom shares the following:

She was a she was she was a white woman, by the way. And she was apologetic to me, was shocked that and hurt that I had to go through this, because she disclosed to me that no one else has experienced this. And she disclosed to me that over the years I was the only and was the first and only Black male that has done a placement with them. And that she has current students who are doing their placement at the same time, including a white female, who has never experienced this coming to placement. 
During the interview Tom also discussed feeling like he was being treated as a criminal

due to being a Black. Maynard (2010) expressed that Black existence in public spaces in itself is criminal and due this Blacks are subject to scrutiny, frequent interruption and police intervention:

I'm doing a service I'm providing a service to the community. There agency is there to respond and provide a service to community members who have been victimized by violence who have been victimized by violence from domestic situations, to violence situations, which could be gun violence, domestic violence situations, people in the community that need help who are in crisis. I'm there doing community work, providing a service and making honest living. I'm coming in to fulfill my educational obligations. But I'm treated like [I] am a criminal.

\section{Psychological Impact}

One of the last themes that stood out during Tom's interview was the psychological impact from anti-Black racism and a phrase that stood out was, "Armor yourself".

On many different levels. As I said, prior to my placement when I knew where my placement was going to be, psychologically I was already prepared. So psychologically, as a Black man you kind of... prepare kind of armor yourself. When you know there's going to be any encounter with the police unfortunately you know what the likely what the likely experience is going to be, which is sad in itself.

Mullings, Morgan, and Quelleng (2016) refer to Toronto police officers shooting and killing of Black males. They note that at least 18 out of $51(35 \%)$ people killed by police since 1990 are Black males. Also, Black men in Canada continue to pay the price for their Blackness which is death. Tom goes on to talk about growing up and being psychologically affected in life and feeling inferior due to anti-Black racism:

When you are victimized by... racism, anti-Black racism, your entire life it disrupts you psychologically on many different levels. It go you go through phases in your life you go through phases in whereas I explained to you as a child, you believe it, you believe at some point that you're less you're inferior.

\section{Analysis}

\section{Experiential Knowers of Racism}


The Black and White epistemology was evident throughout both Jim and Tom's lives. Hunter (2002) discuses that its roots are in contemporary racism during the American chattel slavery and it points to slavery as the origin of racism. This epistemology focuses on structural inequalities and discrimination in areas such as education, occupation, and income. Hunter (2002) elaborates that users of this epistemology believe that African Americans have had the most authentic and direct experience with racism. As a result, due to Black people's experience of racism, they would know how it operates, how to make sense of discrimination and why people hold on to certain attitudes. Also, Hunter (2002) shares that this epistemology also believes that African Americans have an extensive experience with racism and should be interviewed but not to be depended on to provide expert knowledge on racism.

Tom shared how racism/discrimination has always been a part of his day-to-day life:

I'm dealing with it professionally, within my community, um dealing with it in the educational system, employment opportunities, employment opportunities being denied. Um seeing people exercising their privilege, based on the color of their skin.

Jim speaks to when he and his father were turned away for their furnace services after being contacted by a white couple; this couple however later denied their services when they realized that Jim and his father were Black:

So we use to go around cleaning people's furnaces and stuff like that. One incident where we use to send out flyers right and this guy his wife called and she wanted her furnace cleaned. So she made an appointment with us. But when she was talking to us on the phone, like she didn't know we were black. So I think that's the only reason why she wanted us to come but I feel like if she had known that we were black. She She wouldn't have made us come but anyways, we went there and then when we went there they turned us back. There like Oh, we don't want you guys cleaning our house.

My dad's like why you already booked the appointment. And she's like yeah um I did book the appointment and the husband was there as well. And there like we did we did 
booked the appointment but um we didn't know you guys were like Black like, you know, we thought you guys are ahh like us, like white. So my dad's looking ahh at the lady and the husband like huh Are you serious? So we ended up just leaving and um yeah that was another experience that that I had to deal with too and that was a very bad experience because that was with my dad so yeah, man.

Mullings, Morgan, and Quelleng (2016) mention how anti-Black racism is manifested in the current social, economic, and political marginalization of African Canadians. Anti-Black racism is evidenced in the lack of opportunities, lower socio-economic status, high unemployment, significant poverty rates, and overrepresentation of Black people in the prison system.

\section{Anti-Black-African Racism in China}

A theme that stood out from Jim's experience that will be analyzed was being racially discriminated against by Chinese restaurants. Historically China has had a long history of practicing anti-Black racism against African people and Jim experienced discrimination by not one but two Chinese restaurants. Cheng (2011) mentions that historically the socialization of African people in China has viewed African people as inferior, lazy and stupid. Historically, the racial hierarchy of Black people in China has always been negative. Cheng (2011) addressed the racial hierarchy that has been designated to Whites and Chinese as being "strong and intelligent" and others as "feeble and stupid." Furthermore, it denigrated Blacks as the most inferior human race, as being primitive, unimaginative, savages while also being immoral, ugly, and unintelligent.

The negative and untrue beliefs of African people has had some Chinese people believing that Black people are subordinate and because of these racist ideals some Chinese people have been socially taught to discriminate and treat Black people as inferior. Cheng (2011) talks about the historical racial hierarchy in China that has categorized Black people as individuals who 
bring crime and poverty to nations. Therefore, Africans are almost universally looked down upon in China as people of 'low quality' and many Chinese intellectuals attribute the United States of America's most serious problems such as poverty and crime to its African-American population.

\section{Black Interrogation}

The theory of anti-Black racism will be used to analyze Tom's experience of anti-Black racism within his placement. Tom shared the following:

It wasn't until my placement decided to make noise about it that I started to see slight changes. It wasn't a complete change slight change because still even though they wrote a letter, they went to their department of diversity and inclusion under human resource person. There were still officers that would still interrogate me, even though my name, a description of who I was, including the purpose that I'm coming to placement all that information was there for them to have, they still decided to interrogate me.

The practice of being consistently questioned, targeted and interrogated is also interconnected to stereotypes and racial profiling that Black people consistently experience at the hands of police officers; police officers routinely conduct racist practices in neighbourhoods that are predominantly racialized in which Black people are the targets of their racist policing methods. Mullings, Morgan, and Quelleng (2016) refer to the stereotypes that have been associated to Black males as being prone to criminality, violence and being dangerous. The stereotypes of Black males is observed in the way that police officers engage with Black males, which is connected to the actions of racial profiling. Maynard (2017) shared that racial profiling is also surveillance of Black bodies, which conjure up stereotypes regarding race, ethnicity, or religion. In addition, is the assumption that Black people are likely to be criminals, which results in Black people being watched, caught, and incarcerated.

\section{White Women's Privilege}

A significant theme that stood out during Tom's interview was the connection between intersectionality and the constant interrogation he experienced, compared to the non- 
interrogation of the white female placement students. What stood out for me in Tom's encounters with interrogation was that he was a victim in an institution that practices anti-Black racism, violence, and racial hate of Black bodies; whereas the white female placement students were automatically believed to be good and innocent, while experiencing no form of interrogation by the police officers. Accapadi (2007) asserts that white women carry two societal identities; white women can be both helpless without the helplessness; which is a reflection of all white people while also occupying a position of power as a white person. While in contrast, Black women do not have the option of toggling their identities in this manner.

When a Black woman acts in any way her actions at some level reflect upon her racial community, and she cannot separate her racial identity from her womanhood. Maynard (2017) addressed that white women represent the idealized female subject, while Black women were cast outside of this formation as less than women and less than human.

Also, Accapadi (2017) talks about how the problem for white women is that their privilege is based on accepting the image of goodness, which is powerlessness. This powerlessness informs the nature of white womanhood and through history white privilege positions white woman's reality as the universal norm of womanhood therefore leaving a woman of color to be defined by two layers of oppression. Mullings, Morgan, and Quelleng (2016) speak to how the negative stereotypes of Black women portray them as irrational, angry, involved in sex work and defrauding the system to obtain government benefits. Moreover, Ferber (2007) discusses how women of color are more vulnerable to violent crimes and society responds to the victimization of women based on that woman's status. In addition, Mullings, Morgan, and Quelleng (2016) argue that society, police, prosecutors, and the courts often ignore cases of rape, sexual abuse, and assaults against Black women. 


\section{Chapter 6: Discussion}

\section{Historical Context}

The findings from Jim and Tom's interview depicted the impact slavery has had on the history of anti-Black racism. The narratives by both Jim and Tom highlight how slavery was a major contributor in causing propaganda, hate, oppression, violence, discrimination and prejudice towards Black males. Ferber (2007) discussed how there is documentation on discrimination against Black people in employment, housing, educational institutions, and other institutions; this means that Black people are living with racial oppression from when you are born till when you die. Additionally, Black males have always been viewed as being non-human in comparison to white people. Ray, Randolph, Underhill, and Luke (2017) discuss that slavery produced Blacks as being unequal to whites as well as not having the right to own their own bodies. Due to this, Black males were subjugated to violence, abuse, trauma, and death by police officers who do not view Black males as human beings. Ferber (2007) alludes to Black males being defined as animals and being property to be owned by white men. Also, the racist imagery of Black males doing hard manual labor, justified the harsh conditions forced upon them, which also justified their bodies to be deemed as big, strong, and stupid.

Throughout history there has also been the false belief and fear of Black males being sexually out of control and being a threat to white women's womanhood, if not contained. Ferber (2007) speaks to how upper class whites reduced Black males to their bodies and identified their muscles and penises as their most important physical traits. Furthermore, Maynard (2017) details how protecting white womanhood justified anti-Black states to practice the criminalization of Black men. Secondly, throughout history Black males have been victims to feeling that they are less than in comparison to other races and feeling inferior to whites. Leary (2005) talks about 
post traumatic slave syndrome as a condition that exists among populations that have experienced multiple centuries of trauma. These populations have endured centuries of psychological and emotional enslavement, and continue to encounter systemic oppression and institutionalized racism.

\section{Findings support literature and theoretical frameworks}

The findings of my interviews with Jim and Tom support the literature of anti-black racism and the discrimination that institutions engage in while targeting Black males. Benjamin (2003) discusses that anti-Black racism's roots are in Canada's oppressive history towards Blacks with pervasive policies, and unjust practises by police officers. The findings also support critical race theory and allowed Tom to voice his story of anti-Black racism as well as using a particular approach and artistic way of addressing the systemic discrimination that he experienced while completing his placement. Bell (1995) articulates that not only does critical race theory allow racialized people to voice their stories, but it allows particular racialized individuals to have a race conscious direction and objective to resolve conflicts involving social equalities. Tom shared that he has used poetry to illustrate the anti-Black racism he experienced within his placement. Tom shared the following:

I also did a spoken word, um poem, breaking down the situation. So that in itself was a way of challenging the situation by sharing the story.

\section{Findings from literature and new discoveries}

The findings do not go beyond existing literature and the theoretical frameworks because they address and analyze the anti-Black racism that the participants experienced. The findings 
were consistent with the literature in that they relate to one of the three types of anti-Black racism, namely anti-Black-African racism. The findings resonate with the literature that highlights how anti-Black racism is a global systemic issue that impacts Black males all around the world and not only in the west. The findings that the interviews provided was new knowledge of anti-Black-African racism and its oppression towards Black males in other parts of the world.

The new findings provided literature on anti-Black-African racism in China. Cheng (2011) discusses an anti-African protest by Chinese students in the 1980's which started after African male students were observed having relationships with Chinese women. Sautman (1994) also mentions that Black/African males throughout Chinese history have always been stigmatized as sexual predators and also having a relationship with a Black man is socially unacceptable. The new knowledge provided that though there are many Chinese literatures on nationalism; there are very few on the discourse of race. Cheng (2011) speaks to how there is unlimited literature on Chinese nationalism but what remains less examined is the relationship between nationalism and the discourse of race.

The literature also analyzes that though Chinese people are aware of the racism they experience from the west, they are often blind to their own racism. Cheng (2011) speaks to Chinese people being aware of the racism experienced by the west but often being unaware to their own racism. Consequently, the new knowledge brought forth how the Chinese had adopted the west's racial hierarchy. Sautman (1994) spoke to how at the turn of the century, Chinese intellectuals adopted scientific racism which was influenced by western views. 
The literature also provided knowledge that showed that not only do some Chinese nationals practice anti-Black racism but there are also a few non-Black minority individuals who also participate and commit oppressive acts towards Black people. Eswaren (2015) argues that many third world nationals who live in first world countries, do not always interrogate how they enter racialized hierarchy, wherein the eyes of whites they undoubtedly have greater status and privilege than individuals of African descent. Additionally, Eswaren (2015) discusses that writings on diaspora and moral minorities, interrogate how certain diasporic subjects succeed within capitalist economies, while also contributing to the mistreatment of Black individuals.

\section{Implications for social work education}

The implication for social work practices as it pertains to anti-Black racism and critical race theory is for social work agencies and institutions to acknowledge and listen to stories of anti-Black racism which not only impacts Black males but also Black people. Wehbi and Parada (2019) talk about how though there is documentation of marginalized peoples' experience of racism in the workplace. More social work research is required to critique institutional practices that are situated in historical and globalized systems of white supremacy. Black peoples encounter with anti-Black racism needs to be acknowledged and listened to. Mullings, Morgan, and Quelleng (2016) speaks to how when addressing anti-Black racism, the inclusion of critical race theory centers around hearing the voices and experiences of racism from individuals living in a world where they are dominated systemically, economically, and legally.

Additionally, social work education needs to have more research and literature on the anti-Black-African racism experience in Canada and globally. Puplampu and Tettey (2005) discuss that unlike Asian or Caribbean immigrants where there is quite a significant amount of literature on their experiences of racism, there is less research about continental Africans and 
racism. Puplampu and Tettey (2005) have also referred to it as intellectual marginalization and speak to how the research on the Black population in the west overly focuses on the in-migration of people from English and Spanish speaking Caribbean countries, and not African countries.

\section{Critical reflection on research journey}

As I reflect on my research journey there were not any stories by Jim and Tom that were surprising. Hearing Jim share his story of being discriminated against by the Chinese restaurant did not surprise me due to hearing similar stories of Black people being discriminated against by other marginalized groups. However, I was surprised to hear about the sign saying they do not serve Black people. Hearing about such a display made me realize that white Canadians and other minority groups continue to view Black people as inferior and would engage in their flawed beliefs by putting up a sign to display how they truly feel about Black people. As a result, not realizing the long history of racism that Black people have endured and the significance it entails when being discriminated against as a Black body. Mullen-Gonzalez (2012) speaks to how young Black males experience high rates of trauma due to the unrelenting experiences of prejudices and barriers to success.

In addition to hearing Tom's story about his negative experience with anti-Black racism at his placement, it was also not shocking due to also being a victim of racial profiling, discrimination, and racism by police officers. While also personally knowing Black family members and friends who have been racially oppressed and subjugated by the police. Maynard (2017) argues that the association between Blackness and criminality have granted police largely unchecked authority over Black communities, which allows them to conduct illegal identity checks, searchers, seizures and car stops at a rate unimaginable to non-Black Canadians. 
As I engage in reflexivity on my research journey, a theme that stood out in each participant's interview which I have also experienced; it was the close connection to internalized oppression and anti-Black racism, since I have also experienced internalized oppression from anti-Black racism while growing up as a young Black male in a marginalized community. I believed and internalized the stereotypes, propaganda, and false narratives propagated by society as my truth and due to believing it as my truth I engaged in actions that negatively impacted me as a young Black male. Calafell (2013) addressed how reflexivity forces you to acknowledge the cooperation we engage in while perpetuating the oppression that is living within us. 


\section{Chapter 7: Conclusion}

The main intention for selecting my research topic on the impact of anti-Black racism towards Black males was to bring forward unheard stories to academic research articles and to have their stories be visible, since throughout Canadian history there has not been sufficient literature on the negative encounters and impact that anti-Black racism has on Black males. Mullings, Morgan, and Quelleng (2016) shared that proponents of critical race theory argue that the domination under which Blacks are forced to live under is reflective of Black relations which render Blacks invincible and powerless.

In addition, by having critical race theory as one of my theories it allowed both Jim and Tom to share their narrative stories of anti-Black racism, which is a counter story to the false and negative narratives of Black males. The anti-Black racism that Black males encounter across the world depicts how strong and impactful the historical narrative and false images of Black males have had on other marginalized groups. Ferber (2007) argues that the false images of Black males naturalize and reinforce racial inequality and reinforces the message that Black men are naturally aggressive, violent, unsuccessful, unprofessional, not good fathers, and in need of being controlled by white males.

Secondly, incorporating anti-Black racism as a second theory highlighted not only the external struggles that Jim and Tom encountered by being discriminated and racially profiled against but also feeling inferior and internalizing it as truth. Thirdly, Benjamin (2003) talks about how anti-Black racism must be contextualized with Black radical traditions which provide theoretical and political concepts, and understandings with which to frame Black struggles. Within these struggles are thoughts centred around Garveyism, Black/culturalism and Afrocentrism. As a Black/African social worker, my personal epistemology is viewed through an 
Afrocentric lens which is centred on incorporating African ideals which favour and privilege Black/African people, while also building and supporting Black service users, agencies, and initiatives. For this reason, my main goal is to put Black people's needs and concerns first when they are seeking assistance in social work related institutions.

In conclusion, until society is willing to acknowledge the effects and impact that antiBlack racism has had not only had on Black males but also Black people as a whole, then systems and institutions will continue to operate through a white, western, and European lens. This will continue to cause more harm and trauma to Black people in spaces where whiteness and white supremacy prevails, while continuing to colonize Black bodies. 


\section{Appendix A: Recruitment Phone Script \\ RYERSONUNIVERSITY}

Hello, John Doe, I am conducting a research study on the experiences of anti-Black racism among Black males living in Canada. This research will hopefully shed light on the impact that anti-Black racism has had on Black males. If you volunteer to participate in this study, you'll be asked to answer questions about the research study, which will be held at Ryerson's library study rooms. This study has received approval from the Ryerson Research Ethics Board.

If you are interested in participating, a consent form will be given before the interview proceeds, to remind you of your right to withdraw from the research if you ever feel discomfort to continue before, during or after the interview. Thank you 


\section{Appendix B: Interview Questions}

1. Can you tell me a bit about yourself and where you grew up?

2. What are some experiences of anti-Black racism while living in Canada?

3. Can you tell me about a story that displays this clearly?

4. Did you challenge or combat that experience? How did you? And if not how come?

5. How did the experience impact you psychologically?

6. What did you learn about yourself and from that experience?

7. Would you have done anything different now looking back at it? If so what? If not how come?

8. Since then have you experienced any other forms of discrimination?

9. What were the tools or skills that you have acquired that have empowered you after the experience?

10. What are some suggestions or requirements that you have for institutions to address acts of anti-Black racism that are practiced against African Canadians? 


\section{Appendix C: Consent Form}

\section{RYERSONUNIVERSITY}

\section{Consent Agreement}

You are being invited to participate in a research study. Please read this consent form so that you understand what your participation will involve. Before you consent to participate, please ask any questions to be sure you understand what your participation will involve.

\section{TITLE OF THE STUDY}

The impact of anti-Black racism towards Black males

\section{INVESTIGATORS}

This research study is being conducted by Rick Acheampong. The supervisor is Gordon Pon, from the department of social work at Ryerson University. Also, the study will not be funded by any agencies or organizations. If you have any questions, please contact Rick Acheampong and email address is racheamp@ryerson.ca. The school of social work's contact number 416-9795179.

\section{PURPOSE OF THE STUDY}

The main purpose of this research is to highlight the experiences of anti-Black racism from the lens of Black males living in Canada. The study is about addressing the practices of anti-Black racism and its psychological, emotional, and mental impact on Black males. The study will utilize a narrative approach to qualitative research involving a semi-structured style and individual interviews with three participants. The inclusion and exclusion criteria are stated below. 
Inclusion Criteria:

- Participants who identify as being Black

- lived in Canada for the majority (over 50\%) of their lives

- Identify as a male

- Participants who have experienced anti-Black racism in Canada

\section{Exclusion Criteria:}

- Participants who do not identify as Black

- Has not been raised in Canada during the majority (over 50\%) of their lives (This is due to the research focusing on the lived experiences of anti-Black racism in Canada who are Black males)

- Do not Identify as a male

- Participants who believe they have never experienced anti-Black racism in Canada.

\section{WHAT YOU WILL BE ASKED TO DO OR WHAT PARTICIPATION MEANS}

Participants who agree to participate in this study, will be asked to go to the location of the research interview, held at Ryerson University's study room which is located in the university's library. The expected duration of the participant's involvement is one to two hours. The type of questions asked in the research questions will be about experiences with anti-Black racism. One sample question is: What are some of your experiences of anti-Black racism while living in Toronto and the second sample question: Can you tell me about a story that displays this clearly? Participants will be offered the opportunity to review the rough draft once it is completed. The rough draft will be emailed to the participants to review and will be password protected. If participants choose to review the rough draft, then this may require up to an hour of their time. If participants do decide to have the interview skyped, the consent form will be emailed or faxed to them.

\section{POTENTIAL BENEFITS}

I cannot guarantee, however, that you will receive any benefits from participating in this study. 


\section{WHAT ARE THE POTENTIAL RISKS TO YOU AS A PARTICIPANT}

The potential risks are low/minimal. There is a psychological risk that the participants may feel discomfort during the interview. Participants are notified of their right to withdraw before, during or after the interview. Participants will also be made aware in the consent form that they may withdraw if they ever to feel any discomfort. Reminders are told to participants that they have the right to decline to answer any questions they choose not to answer. A list of resources will also be provided to participants if they are feeling anxiety or discomfort and wish to speak to someone about this. Please see attachment for a copy of these resources.

\section{CONFIDENTIALITY}

Pseudonyms will be inputted into the rough drafts of transcripts and in the final research paper. The data collected from the research will be audio recordings that will be password protected. Participants will have the right to review/edit their parts for the rough draft of the research paper. They will also have the right to be removed from the research paper if they choose to. However after June 15, 2019 they will not be able to remove their data from the study as it would have been integrated into the overall analyses. The Data recordings will be stored electronically in a audio recorder. Data recordings will be kept until the transcription is completed. Once transcription is completed the audio-recording will be deleted. Only the researcher will have access to the data on the consent form. My Supervisor Gordon Pon will not have access to the consent forms and data. A digital recorder will be used as the audio device. Audio files will be uploaded unto my personal computer which is password protected. Audio recordings will not be permanently stored, they will be deleted once the transcription is completed. The audio recorder will be kept secure in a locked locker, which will only be accessible to the researcher. 


\section{INCENTIVES FOR PARTICIPATION}

Participants will not be paid to participate in this study.

\section{COSTS OF PARTICIPATION}

There will be no cost associated with participation.

\section{COMPENSATION FOR INJURY}

By agreeing to participate in this research, you are not giving up or waiving any legal right in the the event that you are harmed during the research.

\section{VOLUNTARY PARTICIPATION AND WITHDRAWAL}

Participants are notified on the consent form that participation is voluntary. Participants will be reminded on the consent form and before the interview, that they do not have to answer every research question. Participant's data can be removed from the study and the cut-off date for data removal is June $15^{\text {th }}, 2019$. It is the final date where participants can no longer remove their data from the study because the information provided will be integrated into analyses by June $15^{\text {th }}$ 2019. Participants will be reminded before during and after the interview that they can withdraw at any time and not have their data included in the study. The choice of participating or not by participants will not influence future relations with Ryerson University and investigator Rick Acheampong. Also, after completion of the paper participants will also be provided a copy of the paper upon request.

\section{QUESTIONS ABOUT THE STUDY}


If you have any questions about the research now, please ask. If you have questions later about the research, you may contact Rick Acheampong, the primary investigator. Ryerson University's contact number is 416-979-5179. Ryerson School of Social Work address is 87 Gerrard Street, Toronto, Ontario M5B 1G6. Email of supervisor Gordon Pon is g2pon@ ryerson.ca. This study has been reviewed by the Ryerson University Research Ethics Board. If you have questions regarding your rights as a participant in this study, please contact: Research Ethics Board c/o Office of the Vice President, Research and Innovation Ryerson University 350 Victoria Street Toronto, ON M5B 2K3

416-979-5042

rebchair@ryerson.ca

\section{Impact of Anti-black racism on Black males} CONFIRMATION OF AGREEMENT

Your signature below indicates that you have read the information in this agreement and have had a chance to ask any questions you have about the study. Your signature also indicates that you agree to participate in the study and have been told that you can change your mind and withdraw your consent to participate at any time. You have been given a copy of this agreement. You have been told that by signing this consent agreement you are not giving up any of your legal rights.

Name of Participant (please print)

Signature of Participant Date 
I understand that by participating in the research. I agree to be audio-/video-recorded for the purposes of this study. I understand how these recordings will be stored and destroyed.

Signature of Participant Date 


\section{References}

Accapadi, M. M. (2007). When white women cry: How white women's tears oppress women of color. College Student Affairs Journal, 26(2), 208.

Atkins-Loria, S., Macdonald, H., \& Mitterling, C. (2015). Young African American men and the diagnosis of conduct disorder: The neo-colonization of suffering. Clinical Social Work Journal, 43(4), 431-441. doi:10.1007/s10615-015-0531-8

Bailey, M. M. (2014). Engendering space: Ballroom culture and the spatial practice of possibility in Detroit. Gender, Place \& Culture, 21(4), 489-507. doi:10.1080/0966369X.2013.786688

Benjamin, L. A. (2003). The Black/Jamaican criminal: The making of ideology. Toronto

Bell, D. (1995) Who's afraid of critical race theory? University of Illinois Law Review, 1995, 893-910

Biafora, F. A., Taylor, D. L., Warheit, G. J., Zimmerman, R. S., \& Vega, W. A. (1993). Cultural mistrust and racial awareness among ethnically diverse black adolescent boys. Journal of Black Psychology, 19(3), 266-281. doi:10.1177/00957984930193003

Brady, S. S., Gorman-Smith, D., Henry, D. B., \& Tolan, P. H. (2008). Adaptive coping reduces the impact of community violence exposure on violent behavior among African American and Latino male adolescents. Journal of Abnormal Child Psychology, 36(1), 105-115. doi:10.1007/s10802-007-9164-X

Brunson, R. K., \& Miller, J. (2006). Young Black men and urban policing in the United States.

Calafell, Bernadette M. (2013). (I)dentities: Considering accountability, reflexivity and intersectionality in the I and the We. Liminalities: A Journal of Performance Studies 9(2), pp. 6-13. Retrieved from: http://liminalities.net/9-2/calafell.pdf

Cheng, Y. (2011). From campus racism to cyber racism: Discourse of race and Chinese nationalism. The China Quarterly, 207(207), 561-579. doi:10.1017/S0305741011000658

Clandinin, D. J., \& Connelly, F. M. (2000). Narrative inquiry: Experience and story in qualitative research (1st ed.) San Francisco Jossey-Bass.

Combs, D. R., Penn, D. L., Cassisi, J., Michael, C., Wood, T., Wanner, J., \& Adams, S. (2006). Perceived racism as a predictor of paranoia among African Americans. Journal of Black Psychology, 32(1), 87-104. doi:10.1177/0095798405283175

Crenshaw, K. W. (1988). Race, reform, and retrenchment: Transformation and legitimation in antidiscrimination law. Harvard Law Review, 1331-1387. 
Creswell, J. W. (2007). Qualitative inquiry \& research design: Choosing among five approaches (2nd ed.). Thousand Oaks Sage Publications

Delgado, R., \& Stefancic, J. (2017). "Introduction" and "hallmark critical race theory themes" In Critical Race Theory: An Introduction. New York, NYU Press. pp. $1-43$

Deliovsky, K., \& Kitossa, T. (2013). Beyond black and white: When going beyond may take us out of bounds. Journal of Black Studies, 44(2), 158-181. doi:10.1177/0021934712471533

Eswaran, N. (2015). "stick[ing] to their own kind": Melancholia and/as anti-black racism in Mira Nair's Mississippi Masala. South Asian Review, 36(3), 97-108. doi:10.1080/02759527.2015.11933036

Fanon, F. (2008 [1952]). Black skin, white masks. New York, NY: Grove Press. (pp. 89-119).

Ferber, A. L. (2007). The construction of black masculinity: White supremacy now and then. Journal of Sport \& Social Issues, 31(1), 11-24. doi:10.1177/0193723506296829

Graham, L. F. (2014). Navigating community institutions: Black transgender women's experiences in schools, the criminal justice system, and churches. Sexuality Research \& Social Policy, 11(4), 274. doi:10.1007/s13178-014-0144-y

Gump, J. P. (2010). Reality matters: The shadow of trauma on African American subjectivity. Psychoanalytic Psychology, 27(1), 42-54. doi:10.1037/a0018639

Hardy, K. V. (2013). Healing the hidden wounds of racial trauma. Reclaiming Children and Youth, 22(1), 24-28

Hunter, M. (2002). Rethinking epistemology, methodology, and racism: Or, is white sociology really dead? Race and Society, 5(2), 119-138. doi:10.1016/j.racsoc.2004.01.002

Khenti, A. A. (2013). Homicide among young black men in Toronto: An unrecognized public health crisis? Canadian Journal of Public Health / Revue Canadienne De Santé Publique, 104(1), e12-e14.

Kumsa, M. K., Mafoafo, M., Oba, F ., \& Gaasim, S. (2014). The contours of anti-black racism: Engaging anti-oppression from embodied spaces. Journal of Critical Anti-Oppressive Social Inquiry, 1, 21-34.

Langhout, R. D. (2006). Where am I? locating myself and its implications for collaborative research. American Journal of Community Psychology, 37(3), 267-274. doi:10.1007/s10464-006-9052-5

Leary, Joy DeGruy. (2005). Post traumatic slave syndrome : America's legacy of enduring injury and healing. Portland, Oregon: Uptone Press. 
Mathebane, M. S., \& Sekudu, J. (2018). A contrapuntal epistemology for social work: An Afrocentric perspective. International Social Work, 61(6), 1154-1168.

doi:10.1177/0020872817702704

Maynard, R. (2017). Policing black lives: State violence in Canada from slavery to the present Fernwood Publishing.

Meerai, S., Abdillahi, I., \& Poole, J. (2016). An introduction to anti-black sanism. Intersectionalities: A Global Journal of Social Work Analysis, Research, Polity, And Practice, 5(3), 18-35.

Molina, K. M., \& James, D. (2016). Discrimination, internalized racism, and depression: A comparative study of African American and Afro-Caribbean adults in the US. Group Processes \& Intergroup Relations, 19(4), 439-461. doi:10.1177/1368430216641304

Mullaly, R. P., \& Mullaly, R. P. (2010). Challenging oppression and confronting privilege: A critical social work approach. Don Mills, Ont: Oxford University Press.

Mullen-Gonzalez, Jennifer (2012) Slavery and the intergenerational transmission of trauma in inner city African American male youth: A model program-from the cotton fields to the concrete jungle, California Institute of integral Studies (p.1-246)

Mullings, D. V., Morgan, A., \& Kere Quelleng, H. (2016). Canada the great white north where anti-black racism thrives: Kicking down the doors and exposing the realities. Phylon: The Clark Atlanta University Review of Race and Culture, 53(1), 20-41.

Padgett, D. (2008). Qualitative methods in social work research (Second ed.) Thousand Oaks SAGE.

Padgett, D. (2017). Qualitative methods in social work research (Third ed.) Thousand Oaks SAGE.

Parks, G. S., \& Jones, S. E. (2008). "nigger": A critical race realist analysis of the n-word within hate crimes law. The Journal of Criminal Law and Criminology (1973-), 98(4), 1305 1352.

Puplampu, K. P., \& Tettey, W. (2005;2006;). The African diaspora in Canada: Negotiating identity \& belonging. Calgary: University of Calgary Press.

Reasons, C., Bige, M., Paras, C., \& Arora, S. (2016). Race and criminal justice in Canada. International Journal of Criminal Justice Sciences, 11(2), 75. 
Ray, V. E., Randolph, A., Underhill, M., \& Luke, D. (2017). Critical race theory, Afropessimism, and racial progress narratives. Sociology of Race and Ethnicity, 3(2), 147158.

Sautman, B. (1994). Anti-black racism in post-Mao China. The China Quarterly, 138(138), 413437. doi:10.1017/S0305741000035827

Sharma, N., \& Wright, C. (2008). Decolonizing resistance, challenging colonial States. Social Justice, 35 20-138. Retrieved from http://www.jstor.org/stable/29768504

Wade, C. V. (2017). Understanding parenting in the black Caribbean population within the context of historical trauma in Toronto. Toronto: University of Toronto.

Wehbi, S., \& Parada, H. (2017). Reimagining anti-oppression social work practice. Toronto: Canadian Scholars.

Wilson, B., \& Sparks, R. E. (1999). Impacts of black athlete media portrayals on Canadian youth. Canadian Journal of Communication, 24(4), 589. doi:10.22230/cjc.1999v24n4a1127 